\title{
Originals
}

\section{The natural history of lymphocyte subsets infiltrating the pancreas of NOD mice}

\author{
A. Signore ${ }^{1,3}$, P.Pozzilli2,3 ${ }^{2,}$ E.A. M. Gale ${ }^{2}$, D. Andreani ${ }^{3}$ and P.C.L. Beverley ${ }^{1}$ \\ ${ }^{1}$ ICRF Human Tumour Immunology Group, University College and Middlesex School of Medicine, \\ ${ }^{2}$ Department of Diabetes and Immunogenetics, St. Bartholomew's Hospital, London, UK, and \\ ${ }^{3}$ Cattedra Endocrinologia (I), Clinica Medica (II), University of Rome "La Sapienza", Roma, Italy
}

\begin{abstract}
Summary. A longitudinal study of lymphocytic infiltration in the endocrine pancreas of non-obese diabetic mice was performed to investigate the role of different lymphocyte subsets in the pathogenesis of diabetes. The incidence of insulitis and the percentage of mononuclear cell subsets in the pancreas were evaluated in non-obese diabetic mice of various ages $(5,9,13,17,22,29$ and 36 weeks). Cryostat sections of pancreas were stained with heamatoxilin-eosin or with different monoclonal antibodies against total $\mathrm{T}$ lymphocytes, helper T lymphocytes, cytotoxic/suppressor T lymphocytes, activated interleukin 2 receptor positive lymphocytes and B lymphocytes. A monoclonal antibody against Class-II antigens was also used. Positive cells were revealed by the immunoperoxidase technique. Insulitis was found in 5 weeks old mice but to a lesser extent than in adult animals. No significant variation between infiltrating cell subsets was found in different age groups. T lymphocytes ranged between $20.4 \%$ and $28.1 \%$, B lymphocytes between $28.8 \%$ and $30.8 \%$ and Class-II positive cells between $22.8 \%$ and $32.2 \%$. Interleukin 2 receptor positive cells ranged between $5.5 \%$ and $8.5 \%$ as detected with AMT- 13
\end{abstract}

monoclonal antibody which recognise the interleukin 2 binding site. A higher percentage of activated cells was observed using another monoclonal antibody (7D4) directed against a different epitope of the interleukin 2 receptor, suggesting the presence of activated lymphocytes with interleukin 2 receptors saturated by interleukin 2. No insulin-containing cells were found to express Class-II molecules as demonstrated by a double immunofluorescence technique. Most infiltrating mononuclear cells were found to be positive for Class-II and L3T4 antigens or to be Class-II positive and express surface immunoglobulins. We conclude that pancreatic infiltration is an early expression of autoimmune phenomena occurring in these mice and that monocytes and B-lymphocytes predominate in the infiltrate. The role of interleukin 2 and interleukin 2 receptor positive lymphocytes in inducing and maintaining the immune response towards $B$ cells is discussed.

Key words: Non-obese diabetic mouse, insulitis, lymphocyte subsets, Class-II antigens, interleukin 2 receptor, insulin-dependent diabetes.
The non-obese diabetic (NOD) mouse spontaneously develops an autoimmune form of insulin-dependent diabetes characterized by a massive lymphocytic infiltration in the endocrine pancreas starting in the first weeks of life [1, 2].

Three diabetogenic recessive genes have been identified in this animal model, one being located in the region coding for the major histocompatibility complex (MHC) antigens [3,4]. Anti-islet cell, anti-salivary duct and others auto-antibodies have been also observed [5, 6] suggesting the involvement of humoral immunity concomitant to cell mediated immunity. Experimental evidence suggests that $T$ lymphocytes play a major role in development of diabetes in the NOD mouse as confirmed by the absence of disease in athymic mice [7] or in mice treated with a monoclonal antibody (MAb) against $\mathrm{T}$ lymphocytes
(anti-Thy1.2) [8]. Amongst Tlymphocytes both T-helpers (L3T4 antigen bearing cells) and T-cytotoxic/suppressors (Lyt 2 antigen bearing cells) are necessary for development of disease [9-11].

Conflicting data have been reported concerning the percentage of lymphocyte subsets infiltrating the pancreas. Some authors have found a prevalence of B-lymphocytes, others of monocytes or T helper lymphocytes $[2,5]$.

In order to clarify the course and type of lymphocytic infiltration, we have investigated the incidence of

Fig. 1. A medium type of insulitis in the pancreas of a 9 weeks old NOD mouse (a) and a severe type of insulitis in a 36 weeks old NOD mouse (b) 

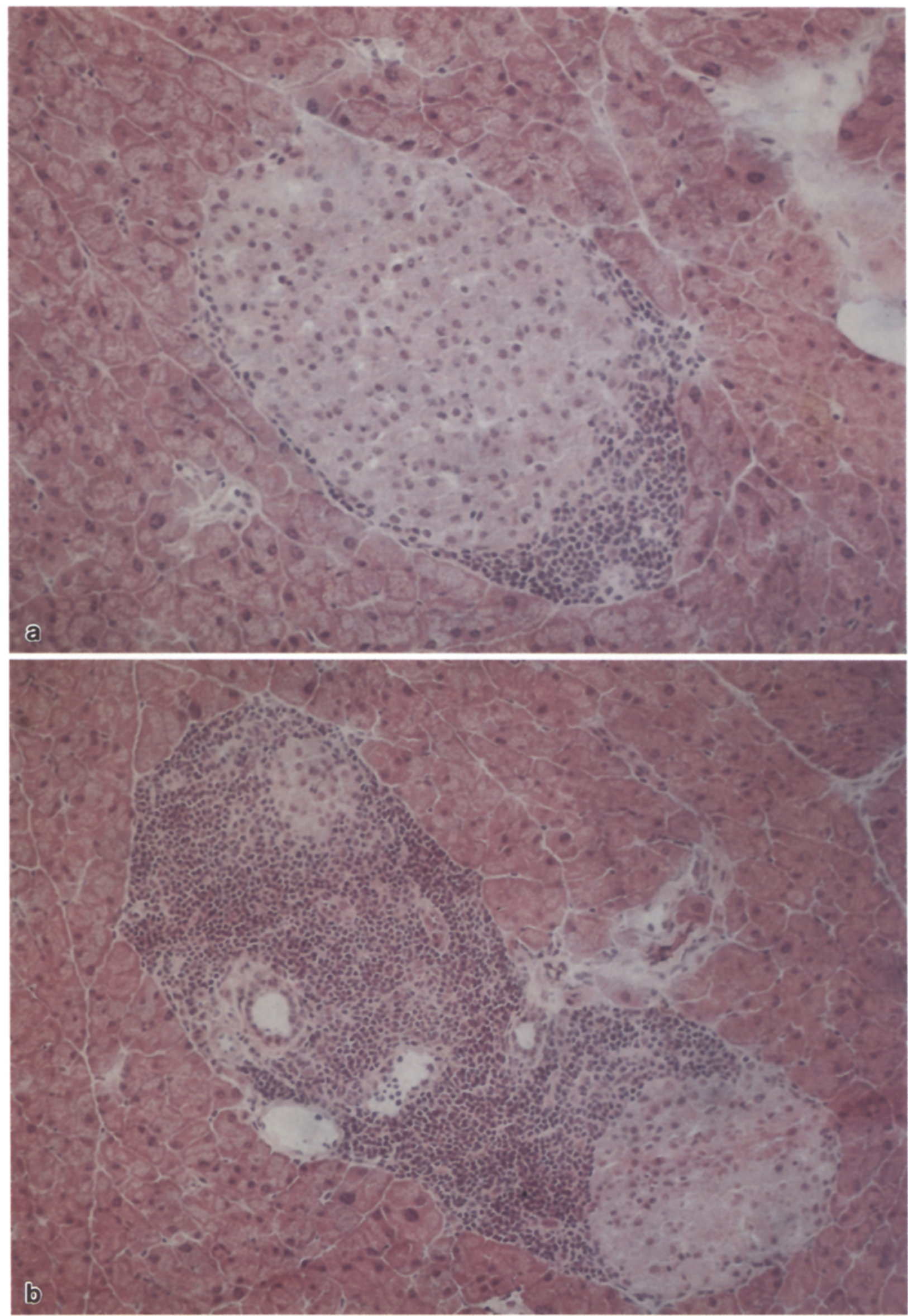
Table 1. Percentage of mononuclear cell subsets in the pancreas of NOD mice

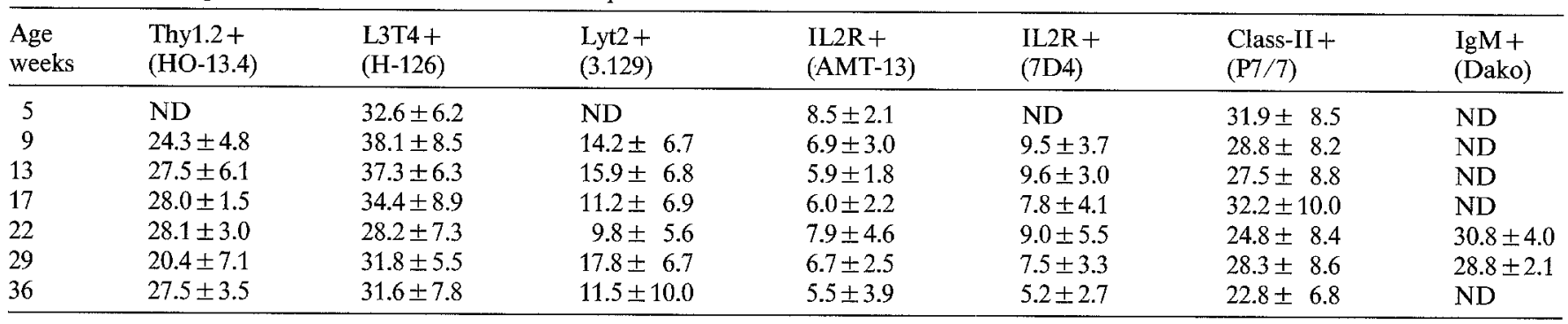

Values are mean $\pm \mathrm{SD}$ at each time point (Lyt2 week 22 vs Lyt2 week $29 p<0.002$ ). ND= not done

insulitis in the natural history of the disease and the variations of mononuclear cell subsets infiltrating the pancreas with particular regard to Class-II + cells and interleukin 2 receptor (IL2R) positive cells.

\section{Materials and methods}

\section{Animals}

A total of 29 NOD female mice (CRC, Transplantation Biology Centre, Harrow, Middlesex, UK), were used for this study. They were part of a colony donated by E. H. Leiter (The Jackson Laboratory, Bar Harbor, Me, USA) [4]. The incidence of diabetes is $60-70 \%$ in females and $15-20 \%$ in males by the age of 36 weeks. They were reared on a commercial diet and tap water ad libitum.

Animals were killed at the age of $5(n=3), 9(n=5), 13(n=4), 17$ $(n=5), 22(n=4), 29(n=4)$, or $36(n=4)$ weeks, the pancreas removed and immediately frozen in liquid nitrogen and stored until immunohistochemical studies were performed.

\section{Histological examination}

The tail of pancreas was chosen for each animal because of the higher islet content. Cryostat sections were prepared as follow: 9 consecutive $5 \mu \mathrm{m}$ sections were cut and put on different slides; approximately after $300 \mu \mathrm{m}$, another 9 consecutive sections were cut and put on the slides. This was repeated 5 or 6 times, thus each slide had 5 or 6 different sections which allows the identification of 10 to 30 islets. One slide served for morphological analysis and the other 8 for immunohistochemical studies.

For morphological analysis sections were stained with haematoxilin-eosin and examined in blind at $250 \times$ magnification using a microscope with an ocular grid. Islet infiltration was scored as mild if lymphocytes were present as a ring around the islet and no more than 100 lymphocytes were usually counted; medium, if lymphocytes were in higher number $(100$ to 1000$)$ around the islet with infiltrated area smaller than islet tissue area; severe, if infiltrated area was larger than islet tissue area and lymphocytes were also present inside the islet altering its normal architecture (Fig.1). The percentage of infiltrated and non infiltrated islets was then calculated at each time point.

\section{Immunoperoxidase staining}

Remaining sections were fixed for $30 \mathrm{~min}$ in acetone at room temperature and stained with the following monoclonal antibodies: HO-13.4 (biotin conjugated anti-Thy1.2) which defines T lymphocytes, H-126 (anti-L3T4) which defines lymphocytes of the helper subset and some monocytes, 3.129 (anti-Lyt2) which defines lymphocytes of the cytotoxic/suppressor subset, P7/7 (reactive with both I-A and I-E molecules of $\mathrm{H}-2^{\mathrm{b}, \mathrm{d}, \mathrm{f}, \mathrm{k}}$ haplotypes) for Class-II + cells [12], AMT-13 (antiIL2R) which recognizes the interleukin 2 (IL2) binding site on activated T lyraphocytes [13] and 7D4 (anti-IL2R) which binds to a different epitope of the IL2R and does not compete with IL2 or AMT13 [14]. In mice of 22 and 29 weeks of age, B lymphocytes were also detected by incubating sections for $1 \mathrm{~h}$ with a biotin-conjugated rat anti-mouse immunoglobulin M (IgM) MAb (Dako).

After $1 \mathrm{~h}$ incubation, $30 \mu \mathrm{l}$ of peroxidase conjugated rabbit anitrat immunoglobulins (Ig) (Dako P260) diluted 1:50 in tris-buffered saline (TBS) plus 10\% normal mouse serum were added to sections for $45 \mathrm{~min}$. Biotin conjugated first antibodies were revealed by a second incubation with $30 \mu \mathrm{l}$ of peroxidase conjugated avidin (Dako P364, High Wycombe, Bucks, UK) diluted 1:500 in TBS. One slide served as negative control and was stained only with second antibody. All sections were then treated with diaminobenzidine (DAB) and counterstained with Mayer's haematoxilin [15].

The percentage of positive cells was evaluated by counting $300-1000$ cells in blind in 5-10 different islets for each pancreas using an ocular grid at $400 \times$ magnification.

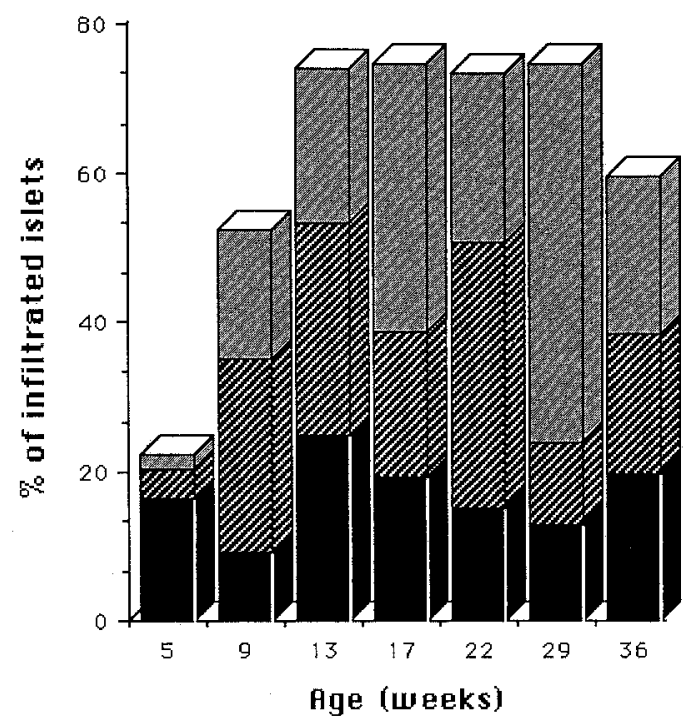

Fig. 2. Percentage of infiltrated islets in NOD mice of different ages. Two mice of 22 weeks and three mice of 29 weeks were diabetic of recent onset. Plain bars $(\square)$ represent islets with mild infiltration, hatched bars (ख) medium infiltration and gray bars (10) severe infiltration

Fig. 3. Immunoperoxidase staining of cryostat pancreas sections of a 36 week old NOD female mouse using different monoclonal antibodies defining Thy1.2 + T lymphocytes (a), L3T4 + cells (b), Lyt2 + lymphocytes (c) and Class-II + cells (d) 

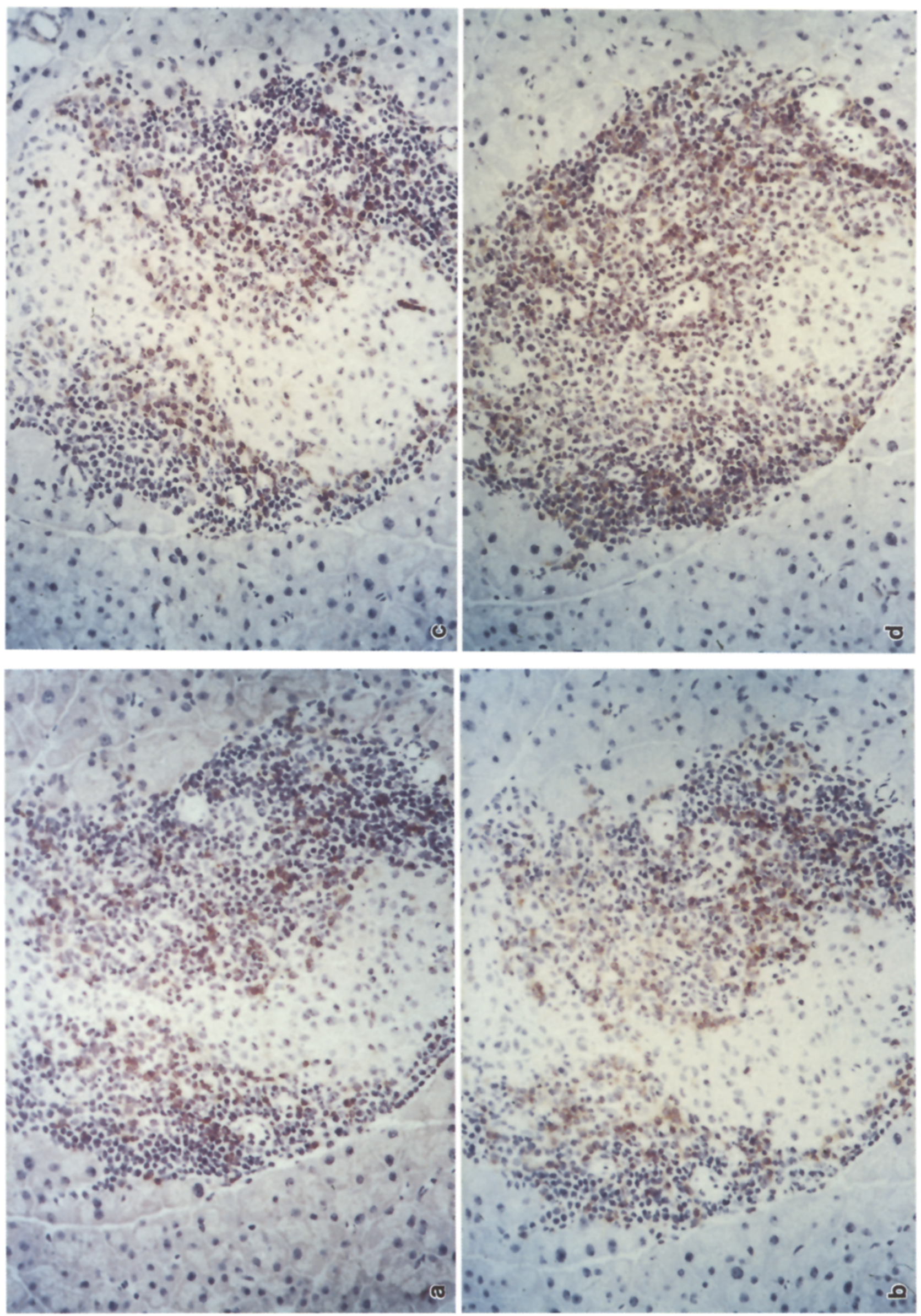


\section{Immunofluorescence staining}

For double immunofluorescence studies, other cryostat sections were cut and fixed in acetone before staining with two MAb: the first (rat MAb) was revealed by a second incubation with FITC-conjugated rabbit anti-rat Ig (Dako F234) 1:50 TBS and the second, biotin-conjugated $\mathrm{MAb}$, was revealed by a further incubation with Texas-red conjugated streptavidin (Amersham RPN-1233 Buckinghamshire, UK) 1:50 TBS.

After the incubation with FITC-conjugated Ig and prior to the incubation with the second antibody, sections were incubated for $30 \mathrm{~min}$ with normal rat serum to avoid non-specific binding of second antibody to the FITC-conjugated Ig. For insulin staining, a guinea pig anti-human insulin serum $(1: 100)$ reacting also with mouse insulin and biotin conjugated goat anti-guinea pig IgG (Sigma Poole, Dorset, UK) $(1: 100)$ were used followed by incubation with Texas-red streptavidin. Sections were then examined under an UV microscope using two different filters to visualise alternatively fluorescein or Texas-red.

\section{Statistical analysis}

Analysis of variance (ANOVA) was used to evaluate differences in the percentage of infiltrating cell subsets in animals of the same age and different ages; unpaired Student's $t$ test was used for comparison of data obtained with AMT-13 and 7D4 MAb.

\section{Results}

\section{Histological examination}

Time course analysis of histological changes in the pancreas of NOD mice revealed that at 5 weeks $22 \%$ of islets were infiltrated and that insulitis is predominantly mild (Fig. 2). In older mice, the percentage of infiltrated islets increased to nearly $80 \%$, and insulitis became more severe with loss of islet architecture; however, we never observed necrotic islets. The maximum incidence of diabetes occurred between 22 and 25 weeks of age in our colony. In those mice examined at 36 weeks of age and which did not developed diabetes, the number of infiltrated islets was slightly lower as well as the severity of insulitis.

\section{Immunoperoxidase staining}

Immunohistochemical study of pancreas sections revealed that the predominant cell subset infiltrating the pancreas was L3T4+ (Fig.3). No significant changes in the distribution of cell subsets were observed in mice at differing ages (Table 1), nor did the percentage of IL2R + cells, as evaluated with either AMT-13 or 7D4 Mab. However, in all age groups except in 36 weeks old mice, more cells were stained by 7D4 than AMT-13. This difference was more evident in younger mice and was statistically significant only in mice of 9,13 and 17 weeks of age $(p<0.02, p<0.002, p<0.05$ respectively, Fig.4). Furthermore, a significant difference in Lyt $2+$ cells was found between mice of 22 and 29 weeks of age $(p<0.002$; unpaired Student's $t$ test),

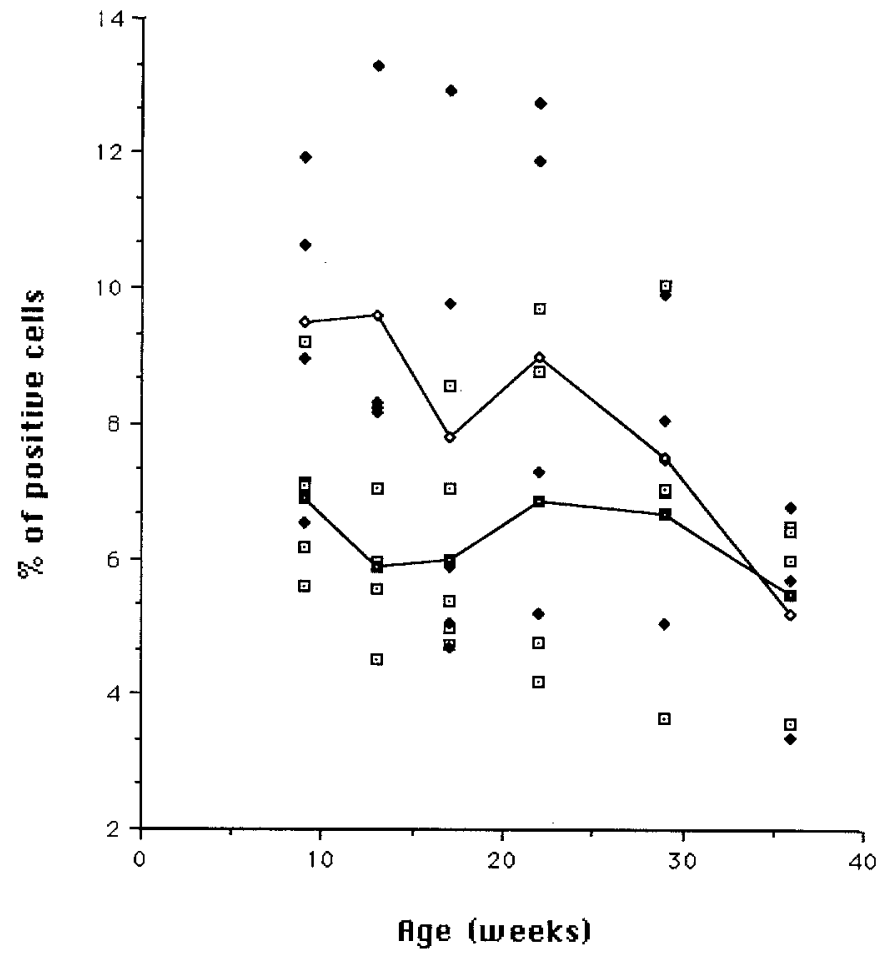

Fig.4. Percentage of activated $\mathrm{T}$ lymphocytes in the pancreas of NOD mice as detected by 7D4 $(\diamond)$ and AMT-13 $(\nabla)$. Lines $(\diamond$ for 7D4 and $\square$ for AMT-13) are mean of data at each time point. $(p<0.02$ at 9 weeks; $p<0.002$ at 13 weeks; $p<0.05$ at 17 weeks)

(Table 1). Among all animals studied, Class-II + cells ranged between 17.5 and $47.8 \%$, B lymphocytes between 28.0 and $35.4 \%$, both subsets being more numerous than total $\mathrm{T}$ lymphocytes $(17.9-28.2 \%)$.

\section{Immunofluorescence staining}

Double immunofluorescence staining for insulin and Class-II antigens showed no Class-II + insulin containing cells, confirming results obtained with immunoperoxidase technique. A large overlap was observed staining sections for L3T4 and Class-II antigens or for IgM and Class-II. No overlap was observed between Thy 1.2 and Class-II (Fig. 5) or Lyt2 and Class-II; IL2 receptors were not found associated with Class-II + cells.

\section{Discussion}

Lymphocytic infiltration in the endocrine pancreas is the histological hallmark of human Type 1 (insulin-dependent) diabetes. NOD mice represent an ideal animal model to investigate such an immune phenomenon. We have studied the natural history of insulitis and the phenotype of mononuclear cell subsets infiltrating the pancreas in these animals over their life span.

As previously reported, insulitis was evident as early as the 5 th week of age $[1,2,5,16]$ and increased until the onset of diabetes which, in our colony, occurs between the 22 nd and 25 th week of age. We also observed that 

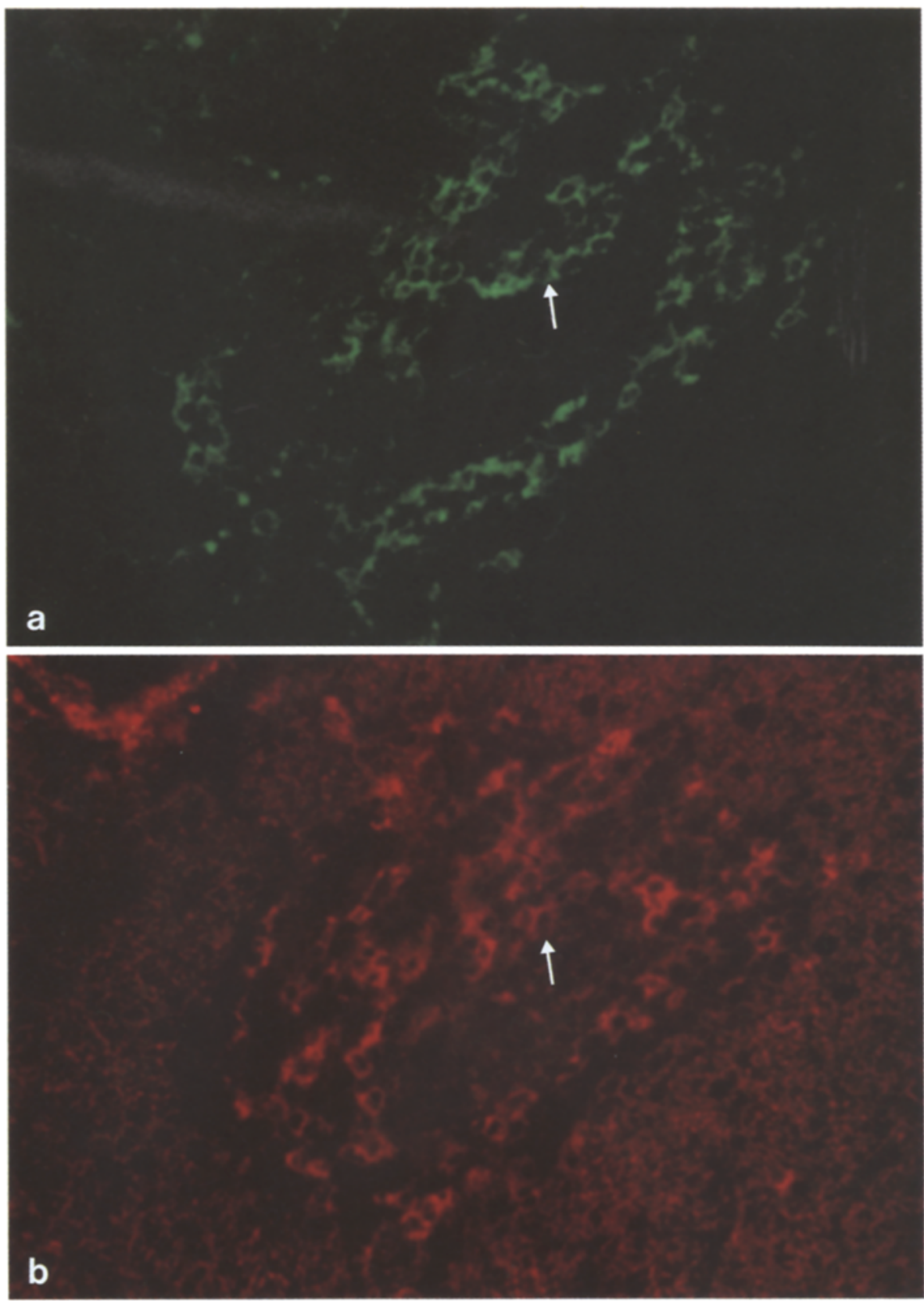

Fig.5. A cryostat pancreas section of a 29 week old NOD mouse stained with $\mathrm{MAb}$ against Class-II antigens $(A)$ and Thy1.2 antigens (B). Class-II was revealed by fluorescein conjugated second antibody and Thy 1.2 by Texas-red conjugated second antibody. We were able to identify only one double positive cell (white arrow $\Rightarrow$ )

concomitant to the increase of islet infiltration, B-cell mass starts to decrease. When all $B$ cells have been destroyed, lymphocytes abandon the islet. This was particularly evident in diabetic mice of 22 and 29 weeks of age in which we found that all non-infiltrated islets were small and lacking B cells (Fig.2).

The BB/W rat is another animal model for insulindependent diabetes but, unlike NOD mice, they develop insulitis a much shorter time before the onset of diabetes and show substantial immunological abnormalities which are less marked in NOD mice [17-19].

These findings suggest that the diabetic syndrome in NOD mice offers a better model of human Type 1 diabetes. Moreover, the pre-diabetic period in NOD mice is also characterised by the presence of islet cell auto-antibodies (ICA) which are frequently detected between the 12th and 18th week, later than the histological evidence of insulitis [5, 6]. In humans, the presence of ICA and other auto-antibodies and abnormalities of cell mediated immunity have been detected up to eight years before the onset of diabetes $[20,21]$ and insulitis may already be present at this stage. Howevar, histological data available in humans are reported only at diagnosis [22] when more than $90 \%$ of B cells are already destroyed and all lymphocyte subsets, including activated $\mathrm{T}$ cells, have been identified in the insulitis [23]. Class-II expression by $B$ cells has also been demonstrated in Type 1 diabetes; whereas, we never found Class-II + B cells in NOD mice using the P7/7 MAb as also reported in a previous publication [24].

The results of our immunohistochemical study in NOD mice revealed that $\mathrm{L} 3 \mathrm{~T} 4+$, Class-II + and surface 
$\operatorname{IgM}+$ cells are the predominant subsets detectable in insulitis. As different mononuclear cell subsets may share some antigens, we performed double immunofluorescence staining on pancreas sections in order to further define the phenotype of cell subsets infiltrating the islets. We found that not all L3T4 + cells were Tlymphocytes (Thy1.2+) indicating that L3T4 antigen is expressed also on surface of other mononuclear cells, probably monocytes, as it has been reported for human monocytes [25]. Further evidence of this come from the observation that some L3T4 + cells also expressed Class-II antigens, but we did not find Class-II antigens on Thy1.2+ lymphocytes, and it is still doubtful whether murine Tlymphocytes can express Class-II antigens [26, 27]. This implies that Class-II + cells are more likely to be monocytes and B lymphocytes than Tlymphocytes. The cell subset identified with an anti-surface IgM antibody may also include monocytes, in addition to B lymphocytes, as confirmed by the finding of some overlap in staining with anti-Class-II and anti-IgM.

We conclude that monocytes are the most represented mononuclear cell subset infiltrating the pancreas. This may have important implications in the pathogenesis of the disease as monocytes have been shown to be relevant in the induction and maintenance of insulitis [28, 29].

Previous reports on the histopathology of pancreas in NOD mice have identified B lymphocytes as the major infiltrating cell subset [5]; others found that L3T4+ and Class-II + mononuclear cells were the most represented subsets in infiltrated islets [2]. However, Class-II + cells were interpreted as activated $\mathrm{T}$ lymphocytes [2], but our double immunofluorescence experiments showed the absence of IL2R on most Class-II + cells. We recently reported that activated lymphocytes are better defined by the presence of IL2R [24]; thus, in the present study, we characterised activated lymphocytes using two different MAb; AMT-13 which competes with IL2 for the same binding site [13] and 7D4 which recognises a different epitope on the IL2R [14].

We found that the percentage of IL2R + cells ranged between $3.6 \%$ and $11.6 \%$ of the total infiltrating cells, thus representing approximately up to $30 \%$ of T lymphocytes. The difference observed using the two MAb may be attributed to a high secretion of IL2 which binds to cell associated receptors on Tlymphocytes, thus inhibiting the binding of AMT-13 but not of 7D4 MAb. Therefore, the use of a MAb, which competes with IL2 for the same binding site on cell receptors, may lead to underestimating the number of activated lymphocytes. It is of interest that a difference between the percentage of AMT-13+ and 7D4+ cells was found only in young mice before the onset of diabetes. This finding suggests that IL2 secretion is high in the early phase of insulitis and tends to decrease when B cell mass diminishes. This phenomenon may be relevant for induction and maintenance of an immune response towards B cells [30].
These findings enphasise the importance of activated $T$ lymphocytes in the pathogenesis of the disease justifying new approaches with selective immunotherapy based on suppression of inhibition of activated IL $2 R+T$ lymphocytes for the cure and prevention of Type 1 diabetes [31].

Acknowledgments. The authors wish to thank Dr. E. Simpson for supplying NOD mice, Dr. T. Diamanstein and Dr. G. Butcher for monoclonal antibodies, Dr. A. Hayward and Dr. A.Cooke for useful suggestions and discussion. This work was partially supported by grants from "Consiglio Nazionale delle Ricerche" (CNR) (bilateral project n. 87.0020204) and the "Centro Internazionale Studi Diabete" (CISD). A.S. is a recipient of a fellowship from the Juvenile Diabetes Foundation.

\section{References}

1. Fujita F, Yui R, Kusumoto $Y$, Serizawa $Y$, Makino $S$, Tochino $Y$ (1982) Lymphocytic insulitis in 'Non-Obese Diabetic (NOD)' strain of mice: an immunohistochemical and electron microscope investigation. Biomed Res 3: 429-443

2. Miyazaki A, Hanafusa T, Yamada K, Miyagawa J, Fujino-Kurihara H, Nakajima H, Nonaka K, Tarui S (1985) Predominance of Tlymphocytes in the pancreatic islets and spleen of prediabetic non obese diabetic (NOD) mice: a longitudinal study. Clin Exp Immunol 60: 622-630

3. Hattori M, Buse JB, Jackson RA, Glimcher L, Dorf ME, Minami M, Makino S, Moriwaki K, Kuzuya $H$, Imura $H$, Strauss WM, Seidman JG, Eisenbarth GS (1986) The NOD mouse: recessive diabetogenic gene in the major histocompatibility complex. Science 231: 733-735

4. Prochazka M, Leiter EH, Serreze DV, Coleman DL (1987) Three recessive loci required for insulin-dependent diabetes in nonobese diabetic mice. Science 237: 286-289

5. Kanazawa Y, Komeda K, Sato S, Mori S, Akanuma K, Takaku F (1984) Non-Obese-Diabetic mice: immune mechanisms of pancreatic B-cell destruction. Diabetologia 27: 113-115

6. Pontesilli O, Carotenuto P, Gazda LS, Pratt PF, Prowse SJ (1987) Circulating lymphocyte populations and autoantibodies in nonobese diabetic (NOD) mice: a longitudinal study. Clin Exp Immunol 70: 84-93

7. Makino S, Harada M, Kishimoto Y, Hayashi Y (1986) Absence of insulitis and overt diabetes in athymic nude mice with NOD genetic background. Exp Anim 35: 495-498

8. Harada M, Makino S (1986) Suppression of overt diabetes in NOD mice by anti-thymocyte serum or anti-Thy 1,2 antibody. Exp Anim 35: 501-504

9. Bendelac A, Carnaud C, Boitard C, Bach JF (1987) Syngeneic transfer of autoimmune diabetes from diabetic NOD mice to healthy neonates. J Exp Med 166: 823-832

10. Wang Y, Hao L, Gill RG, Lafferty KJ (1987) Autoimmune diabetes in NOD mouse is L.3T4 T-lymphocyte dependent. Diabetes 36: $535-538$

11. Shizuru JA, Taylor-Edwardd C, Banks BA, Gregory AK, Fathman CG (1988) Immunotherapy of the Nonobese Diabetic mouse: treatment with an antibody to T-helper lymphocytes. Science 240: $659-662$

12. Momburg F, Koch N, Moller P, Moldenhauer G, Butcher G, Hammerling GJ (1986) Differential expression of Ia and Ia-associated invariant chain in mouse tissues after in vivo treatment with IFN- $\gamma$. J Immunol 136: 940-948

13. Osawa H, Diamenstein $T$ (1984) A rat monoclonal antibody that binds specifically to mouse T lymophoblasts and inhibits IL2 receptor function: a putative anti-IL2 $\mathrm{r}$ Ab. J Immunol 132: 2445-2450

14. Malek TR, Robb RJ, Shevach EM (1983) Identification and initial characterization of a rat monoclonal antibody reactive with the 
murine interleukin 2 receptor-ligand complex. Proc Natl Acad Sci USA 80: 5694-5698

15. Rowe DJ, Isemberg DA, Beverley PCL (1983) Monoclonal antibodies to human leukocyte antigens in polymyositis and muscolar dystrophy. Clin Exp Immunol 54: 327-336

16. Fujino-Kurihara H, Fujita H, Hakura A, Nonaka K, Tarui S (1985) Morphological aspects on pancreatic islets of non-obese diabetic (NOD) mice. Virchows Arch [Cell Pathol] 49: 107-120

17. Yale JF, Marliss EB (1984) Altered immunity and diabetes in the BB rat. Clin Exp Immunol 57: 1-11

18. Dean BM, Walker R, Bone AJ, Baird JD, Cooke A (1985) Prediabetes in the spontaneously diabetic BB/E rat: lymphocyte subpopulations in the pancreatic infiltrate and expression of rat MHC class II molecules in endocrine cells. Diabetologia 28: 464-466

19. Kataoka S, Satoh J, Fujiya H, Toyota T, Suzuki R, Itoh K, Kumagai K (1983) Immunologic aspects of the Nonobese Diabetic (NOD) mouse. Abnormalities of cellular immunity. Diabetes 32: 247-253

20. Pozzilli P, Sensi M, Al-Sakkaf L, Tarn A, Zuccarini O, Bottazzo GF (1984) Prospective study of lymphocyte subsets in genetically susceptible subjects to Type 1 diabetes. Diabetologia 27:132-135

21. Tarn A, Dean BM, Thomas JM, Ingram D, Schewarz G, Bottazzo GF, Gale EAM (1988) Predicting insulin dependent diabetes. Lancet I: $845-850$

22. Bottazzo GF, Dean BM, McNally JM, MacHay EH, Swift PGF, Gamble DR (1985) In situ characterization of autoimmune phenomena and expression of HLA molecules in the pancreas in diabetic insulitis. N Engl J Med 313: 353-360

23. Foulis AK, Liddle CN, Farquharson MA, Richmond JA, Weir RS (1986) The histopathology of the pancreas in Type 1 (insulin-dependent) diabetes mellitus: a 25 year review of deaths in patients under 20 years of age in United Kingdom. Diabetologia 29: $267-274$
24. Signore A, Cooke A, Pozzilli P, Butcher G, Simpson E, Beverley PCL (1987) Class-II and IL2 receptor positive cells in the pancreas of NOD mice. Diabetologia 30: 902-905

25. Talle MA, Rao PE, Westberg E, Allegar N, Makowski M, Mittler RS, Goldstein G (1983) Patterns of antigenic expression on human monocytes as defined by monoclonal antibodies. Cell Immunol 78: 83-99

26. Flavell RA, Allen H, Burkly LC, Scherman DH, Waneck GL, Widera $\mathrm{G}$ (1986) Molecular biology of the $\mathrm{H}-2$ histocompatibility complex. Science 233: 437-443

27. Araneo BA, Yowell RL (1985) MHC-linked immune responce suppression mediated by $\mathrm{T}$ cells bearing I-A-encoded determinants. J Immunol 135: 73-79

28. Lee K, Amano K, Yoon J (1988) Evidence for initial involvement of macrophage in the development of insulitis in NOD mice. Diabetes 37: 989-991

29. Kiesel U, Oschilewski M, Kantwerk G, Maruta M, Hanenberg H, Treichel U, Kolb-Bachofen V, Hartung HP, Kolb H (1986) Essential role of macrophages in the development of Type 1 diabetes in BB rats. Transplant Proc 18: 1525-1527

30. Kolb H, Zielasek J, Treichel U, Freitag G, Wrann M, Kiesel U (1986) Recombinant interleukin 2 enhances spontaneous insulindependent diabetes in BB rats. Eur J Immunol 16: 209-212

31. Kelley VE, Gaulton GN, Hattori M, Ikegami $H$, Eisenbarth G, Strom TB (1988) Anti-interleukin 2 receptor antibody suppresses murine diabetic insulitis and lupus nephritis. J Immunol 140: $59-61$

Received: 4 August 1988

and in revised form: 21 December 1988

Dr. P. Pozzilli

P.O. Box 680

I-00187 Roma

Italy 